\title{
Intermédialités
}

Histoire et théorie des arts, des lettres et des techniques

Intermediality

History and Theory of the Arts, Literature and Technologies

\section{Picture Policies in Documents}

Visual Display and Epistemic Practices

\section{Ines Lindner}

Numéro 15, printemps 2010

exposer

displaying

URI : https://id.erudit.org/iderudit/044673ar

DOI : https://doi.org/10.7202/044673ar

Aller au sommaire du numéro

Éditeur(s)

Revue Intermédialités

ISSN

1705-8546 (imprimé)

1920-3136 (numérique)

Découvrir la revue

Citer cet article

Lindner, I. (2010). Picture Policies in Documents: Visual Display and Epistemic Practices. Intermédialités / Intermediality, (15), 33-51.

https://doi.org/10.7202/044673ar
Résumé de l'article

Cet article analyse la spécificité des relations entre texte et image dans la revue Documents dirigée par Georges Bataille de 1929 à 1930. La disposition visuelle s'avère essentielle dans cette publication : les images n'illustrent pas le texte, elles ne lui sont pas subordonnées. Au contraire, l'interaction dynamique entre les deux compose la force critique qui vient miner tout discours scientifique et idéaliste. Documents n'existera guère plus de deux ans mais devint un catalyseur important pour ses collaborateurs et une source de la pensée postmoderne, notamment à travers ses stratégies visuelles. 


\title{
Picture Policies in Documents
}

\section{Visual Display and Epistemic Practices}

\author{
INES LINDNER
}

T

he Journal Documents existed for only two years, with 15 issues appearing between 1929 and 1930, . Nonetheless, its reception was impressive, the primary interest beeing Bataille. ${ }^{1}$ As a journal, it has been discussed in connection with Surrealism and definitively compared with André Breton's La révolution surréaliste, published between 1924 and $1929 .{ }^{2}$ For the most part, the comparison of the two journals boiled down to a comparison of their respective chief editor's positions. Interest in the differences between Breton and Georges Bataille resulted in a strongly personalized perspective on the two journals. This may explain why Documents has been primarily considered in connection with Bataille's work. ${ }^{3}$ This fixation on Bataille neglects the fact that Documents was a site of dialogue and controversy. Journals not only harbour collections of source material for consideration of various authors wich may be incorporated into their body of his works, ${ }^{4}$ but are also a fabric of pictures and texts, in motion, with their own breath. They are an arena where positions are not only taken but also negotiated. When Documents was founded, Bataille was not yet "Bataille". Only in his confrontation with the term tectonic ${ }^{5}$ Bataille developed the "Informe" in

1. See Denis Hollier, "La valeur d'usage de l'impossible," foreword to the reprint of Documents, Paris, Jean-Michel Place, 1991. Among the most influential re-readers are above all Rosalind Krauss and Georges Didi-Huberman.

2. See Dawn Ades, "Photography and the Surrealist Text," in Rosalind E. Krauss and Jane Livingston (eds.), L'amour fou. Photography \& Surrealism, Washington and New York, Corcoran Gallery of Art and Abbeville Press, 1985, p. 155-162.

3. The exhibition by curator Dawn Ades at the Hayward Galerie "Undercover Surrealism: Picasso, Miró, Masson and the Vision of Georges Bataille," London, 11 May31 July 2006, falls into this group.

4. Dawn Ades made this concrete with the exhibition catalogue: Dada and Surrealism Reviewed, London, Hayward Galerie, 1978.

5. Conor Joyce reconstructed Bataille's way of building terms in confrontation with Carl Einstein in Conor Joyce, Carl Einstein in Documents and his Collaboration with Georges Bataille, Philadelphia, Xlibris, 2003, particularly p. 161-190. 
a piece of only a few lines in the "Dictionary" column. When Rosalind Krauss seized on this term, it became a landmark in postmodern discussions. ${ }^{6}$ Quotations and author-related publications of texts from Documents have not only ensured that the texts be separated from their media context, but have also reduced the pictures to the status of merely decorative extras. ${ }^{7}$ Thus, the explosiveness of the visual strategies is necessarily lost. Some pictures have escaped this fate. The discovery of photography as a key medium ${ }^{8}$ for understanding Surrealism has above all brought photos by André Boiffard back to the fore. Here, however, they have to hold their own against Man Ray's or Raul Ubac's elaborate images and look like mere straight photography ${ }^{9}$-which is only half the story. The first publication which assigned a central role to the pictorial material in Documents was Didi-Hubermann's book La ressemblance informe. ${ }^{10}$ However, this too is an interpretation from the perspective of Bataille's complete works. The arrangement of the pictorial material in this volume follows the pattern of optical evidence. The illustrations are displaced and recombined, which is extremely effective, but also smooths everything out. No one knows better than Didi-Huberman that photography, and especially the arrangement of photographs, help shape forms of knowledge. ${ }^{11}$

Documents. What does this title refer to? An intention to publish source material? Verifiable reports and references? Reports about what? For what purpose? The journal contains no editorial, no statement of intent, no manifesto. Documents is a symbol for 1:1, a formula, with no further specifications, at best perhaps indications. The subtitle enumerates: "Doctrines-Archéologie-BeauxArts-Ethnographie." By the fourth issue, however, the ominous term "Doctrines"

6. See Yve-Alain Bois and Rosalind E. Krauss (eds.), L'informe: mode d'emploi, Catalogue of the Exhibition, Paris, Centre Pompidou, 1996. The first to take up the term informe was Paul Valéry in 1938: "Du sol et de l'informe," in Degas Danse Dessin [1936], Paris, Gallimard, coll. "Idées/Arts," 1965, p. 99-119.

7. See Georges Bataille, Documents, Bernard Noël (ed.), Paris, Mercure de France, 1968; Liane Meffre's presentation of the journal in Carl Einstein, Ethnographie de l'art moderne, Marseille, André Dimanche, 1993.

8. See Rosalind E. Krauss, "The Photographic Condition of Surrealism," The Originality of the Avant-Garde and Other Modernist Myths, Cambridge (Mass.), MIT Press, 1986, p. 87-119.

9. See Krauss and Livingston (eds.), 1985.

10. See Georges Didi-Huberman, La ressemblance informe, ou le gai savoir visuel selon Georges Bataille, Paris, Macula, 1995.

11. Georges Didi-Huberman, L'invention de l'hystérie. Charcot et l'iconographie photographique de la Salpêtrière, Paris, Macula, 1982. 
is replaced without comment by "Variétés." The layout of the journal's front cover is quite simple: black capital letters on a yellow background. This style complements the title well. In contrast, the journal itself is lavishly designed. A third of its pages are filled with pictures. The prints are of high quality: a sign of respectability and simultaneously the basis for the quite unorthodox picture policies that would come to characterize the journal's appearance.

Documents was launched as a first-class quality art journal. It was three times more expensive than the Gazette des Beaux-Arts, also financed by the editor Georges Wildenstein. Interestingly, only one member of the editorial staff had previously dealt with art in a professional capacity: the German writer Carl Einstein, who played a key role in the launch of the magazine. ${ }^{12}$ This was not exactly typical for an art journal. None of the editorial staff had envisioned playing a part in the aesthetic appraisal and arrangement of the art scene. The majority of the contemporary artists featured in the journal belonged to the editors' own circle of friends, including André Masson, a friend and relation of Bataille's; Juan Miro, whose studio was located next to Masson's; Albert Giacometti, who in this period became close friends with Michel Leiris, the son-in-law of the art-dealer Daniel Henry Kahnweiler; Georges Braques, whom Einstein had already met at the Kahnweilers' before the war; and of course, Pablo Picasso, to whom an entire issue is dedicated.

This congenial relationship between artists and writers provided the basis for a whole series of short-lived art journals. However, they do not compare to Documents in presentation or in tone. In Documents, the art is part of an academic discussion and is presented in the context of broader issues with methodological treatments by well-established art historians and other specialists.

12. Carl Einstein had previously published on African sculpture and was an expert on cubism. His public reputation as an art historian was based on Die Kunst des 20. Jahrhunderts, which was published as part of the Propyläen Kunstgeschichte, (Berlin, Propyläen, 1926), reissued in 1928 and 1931. Experts on Einstein have tried to clarify his role in the making of Documents. Klaus H. Kiefer published a letter Einstein wrote in August 1928 to Paul Reber with detailed plans for the first 10 issues of Documents (first published in Klaus H. Kiefer (ed.), Avantgarde-Weltkrieg-Exil. Materialien zu Carl Einstein und Salomo Friedlaender/Myona, Frankfurt am Main and New York, Peter Lang, 1986, p. 112-134). For a comprehensive discussion of Einstein's influence on the magazine by the author, compare Klaus H. Kiefer, "Die Ethnologisierung des kunstkritische Diskurses-Carl Einsteins Beitrag zu Documents," in Hubertus Gassner (ed.), Elan Vital oder das Auge des Eros. Kandinsky, Klee, Arp, Miro, Calder, München, Haus der Kunst, 1994, p. 90-103. 
The first three issues might give the appearance of an academic journal, especially with such an impressive list of institutions represented in the comite de rédaction. Although the journal printed articles on the disciplines of archeology, art and ethnography until its discontinuation, its strategy became clear by the fourth issue: interest did not lie in the academic aspect of the disciplines, but in their objects. The inner circle of the journal staff adopted the methodological forms, copied their style and polemically turned them against the established academic rules. A similar effect could be achieved through the simple combination of texts, of pictures, and of pictures with texts. The zigzag motion between the discipline of organized knowledge and provocative impromptu improvisations gained momentum. Surely, the scholar Gustav Heinrich Ralph von Koenigswald did not know that Leiris would place the severed head of Holofernes between the illustrations accompanying his essay on shrunken heads and masks. ${ }^{13} \mathrm{~A}$ selected detail of a picture by Cranach (fig. 1) creates a visual short-circuit between ethnographic objects and a product of Western high culture. The montage practice applied serves not only to broaden viewpoints, but also as demontage within a structured scientific discourse.

The turning point for the visual strategies in Documents can be found in the fourth issue from 1929. Until that time, photographs were merely a means of reproducing the subjects discussed. Not once did Documents show any interest in artistic photography as other avant-garde journals did. Photographs by Karl Blossfeld, Albert Raenger-Patzsch and André Boiffard are not depicted for their artistic value. Nadar's photographs, admired by photo experts and surrealists alike, were only displayed in order to exhibit once famous persons in their ridiculous looking costumes. The journal's picture policy was not created through visual aesthetics, but rather through the positioning of pictures. This applies to the relation between pictures as well as their relation to the text. What sets Documents apart from other journals is that it makes provocative use of the space between images and the space between images and texts. The basis for the effect is the scientific format of the journal. Contrary to La révolution surréaliste, whose layout was merely copied from the journal La nature, the board took pains to employ scientific authority.

When a self-described scientific journal prints reproductions of art pieces next to photos of banal objects, ethnographica next to carnival masks from neighborhood stationery stores, and Hollywood stars next to etchings from the $19^{\text {th }}$ century, the purpose is certainly not about achieving simple poetic effect. 


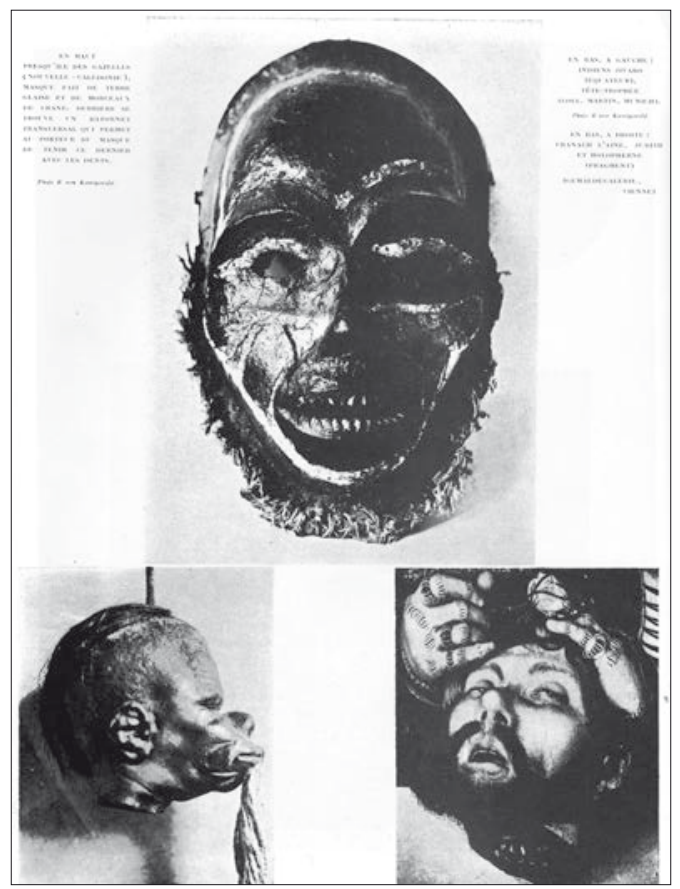

Fig. 1: Ethnographic photographs and a detail from Cranach's Judith and Holofernes. Picture-pages illustrating the article by Ralph von Königswald “Têtes et crânes”, Documents II/6, 1930, p. 356.

Rather, it is a strategy of subversion. The manner in which objects confront one another is not based on some incantation of magical connections nor determined by trans-cultural values. It aims at démontage. Without polemics enmeshed in daily ideological debates, bourgeois certainties and ideals are exposed to attack. The choice of themes is made with an anthropological view devoid of humanistic disguises.

\section{DÉMONTAGE}

The attack on the Western subject was launched via the "figure humaine." This is the headline of one of the central texts of anti-humanism. ${ }^{14}$ The text takes its point of departure from an old-fashioned, provincial wedding photo from the previous generation. Bataille mocked the photo mercilessly in his commentary. It is revealing how the photo, which could easily be replaced with another of the same kind, functions as a stimulus for the text. The text not only exposes this 

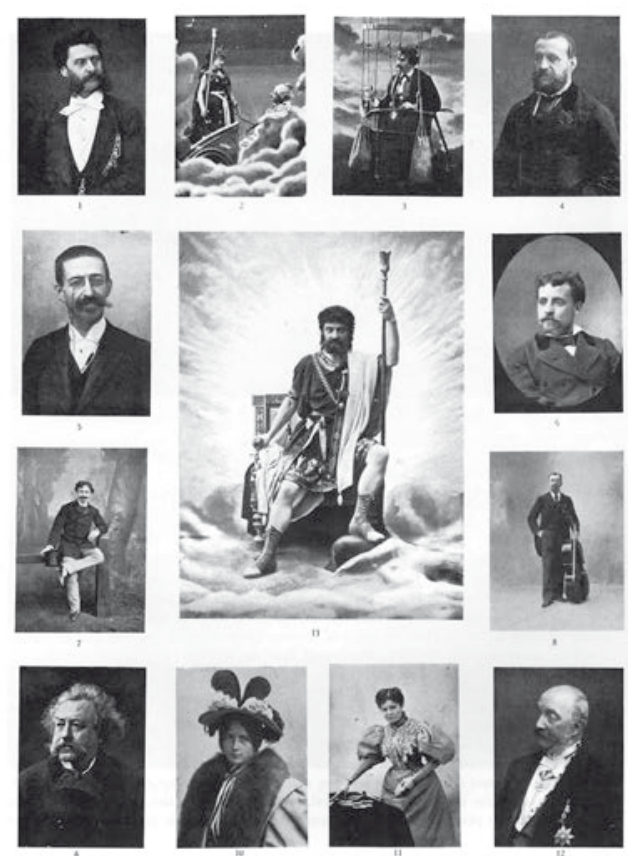

Fig. 2: Photographs by Nadar. Picture-page illustrating Georges Bataille's article "Figure humaine", Documents I/4, 1929, p. 201.

photo to scorn and ridicule, it also affects those that follow, which are compiled and arranged accordingly. The grouping of formerly renowned actors with a Jupiter figure in the middle appears ridiculous (fig. 2). Nadar, who had photographed the dandified protagonists, seems to be scaled down to the level of a commercial photographer immortalizing the vanity of the subjects photographed. But that is not all. With this composition, the surrealists surrounding Breton were also attacked: the informed observer recognizes the template of the photo page with which Breton's group staged their program for La révolution surréaliste. Georges Didi-Huberman confronted the image with its missing counterpart on the double page (fig. 3)..$^{15}$

The movement between picture and text, so characteristic of Documents, can be summarized as follows: it begins with a recovered photo which incites a reflection on the "Figure humaine," which in turn establishes the point of origin for the conception of the photo page 


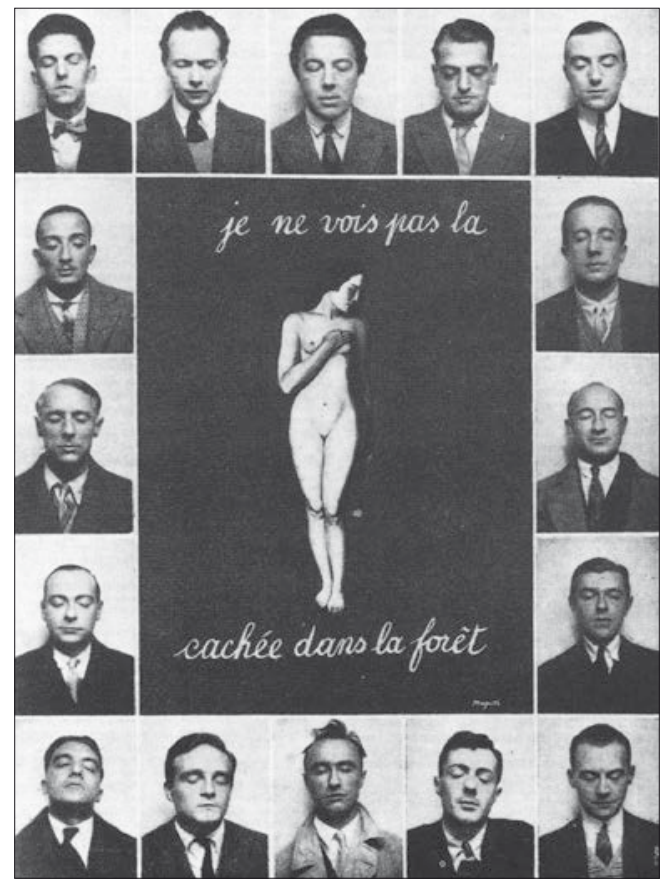

Fig. 3: Photomaton pictures of Breton's group around a painting by René Magritte, La révolution surréaliste $5 / 12,1928$, p. 73.

This is an ingenious example of picture policy, for not only is the dynamics between picture and text an attack on naïve humanism, but also simultaneously ridicules the self-promoting Surrealist circle surrounding Breton (which Bataille, Leiris, and several others from the Documents staff had left). Furthermore it mocks the Breton's relationship to the $19^{\text {th }}$ century and the dream. No names, no arguments, but simply a gesture of contempt, completely uninvolved: this is the strategy of this piece of picture policy. It conforms to the policy from issue to issue for a more assured concept of the journal. Documents infiltrates, experiments, and goes straight to the point.

When one attempts to get an impression of those who were involved in this undertaking, one becomes aware that work on the journal was a phase of reorientation for all. Einstein was stuck on the continuation of his 1912 novel Bebuquin. Bataille, who was twelve years younger and still altogether unknown, had just recently published his first work, the erotic story Histoire de l'œil (1928), though under a pseudonym and as a private publishing venture. Michel Leiris, who at 28 was the youngest member of the group, had not yet decided on a direction 
in his work. He was battling with writer's block. All were attempting to discover their path as writers. However, literature is taboo in Documents. Perhaps their connection to images and the preoccupation with "art" functioned as a catalyst: as non-script. In this way, photography plays a special role. Reference to reality and muteness presents new possibilities for expression, for opening up fields of discourse which can be developed without getting involved with literary standards. The journal creates room for action by its strategy of démontage. It is not only a mode; it is a movement, which seizes that which one does. Leiris would write about Bataille: “(il) fit ‘Documents' en le défaisant..."16

\section{CHRONIQUE-DICTIONNAIRE}

Without the appearance of neutrality, definitions lose their normative impact and thus their reason for being. The entries in the "Chronique-Dictionnaire" rubric feature a field of de-definitions and suggestions for usage. Rankings are subverted here by undermining the intervals which are their very basis. Initially designed to handle abstract concepts, the "Chronique-Dictionnaire" became a field of experimentation and in turn transformed the journal. The texts became shorter and more anecdotal. Their makeshift coexistence through alphabetical order became an impelling force. The alphabet was not handled in lexical order. It changed arbitrarily from issue to issue. In the fourth issue, photos are included for the first time. In the fifth issue, eight photographs are juxtaposed against the seven text entries. The combination of pictures develops its own dynamics. The illustrations do correspond with the entries even though they are not conventional reference book illustrations. They were fished out of a tide of pictures, which flooded the editorial office of Documents. The double page of the fifth issue contained six photos from the "Chronique-Dictionnaire" and fused such heterogeneous images as cinema ads, images of animals, a portrait of a bandaged murderer, and a promotional photo for the furrier's trade (fig. 4). There is no common motive between the images whatsoever. However, they do not appear neutral in their composition. They are purposefully arranged so that one sees them together. It is a grouping that plays with affinities. All the various photos were grouped around the terms human/animal and violence/luxury. The photo Zurichterei (finishing shop) takes on an axial position to which all of the other photos correspond and in which all the above terms are present. The relaxed demeanor of the model wrapped in a fur coat contrasts horrifically with the image of skinned animals on

16. Michel Leiris, "De Bataille l'impossible à l'impossible Documents," Critique, n 195-196 "Hommage à Georges Bataille," August-September 1963, p. 693. 


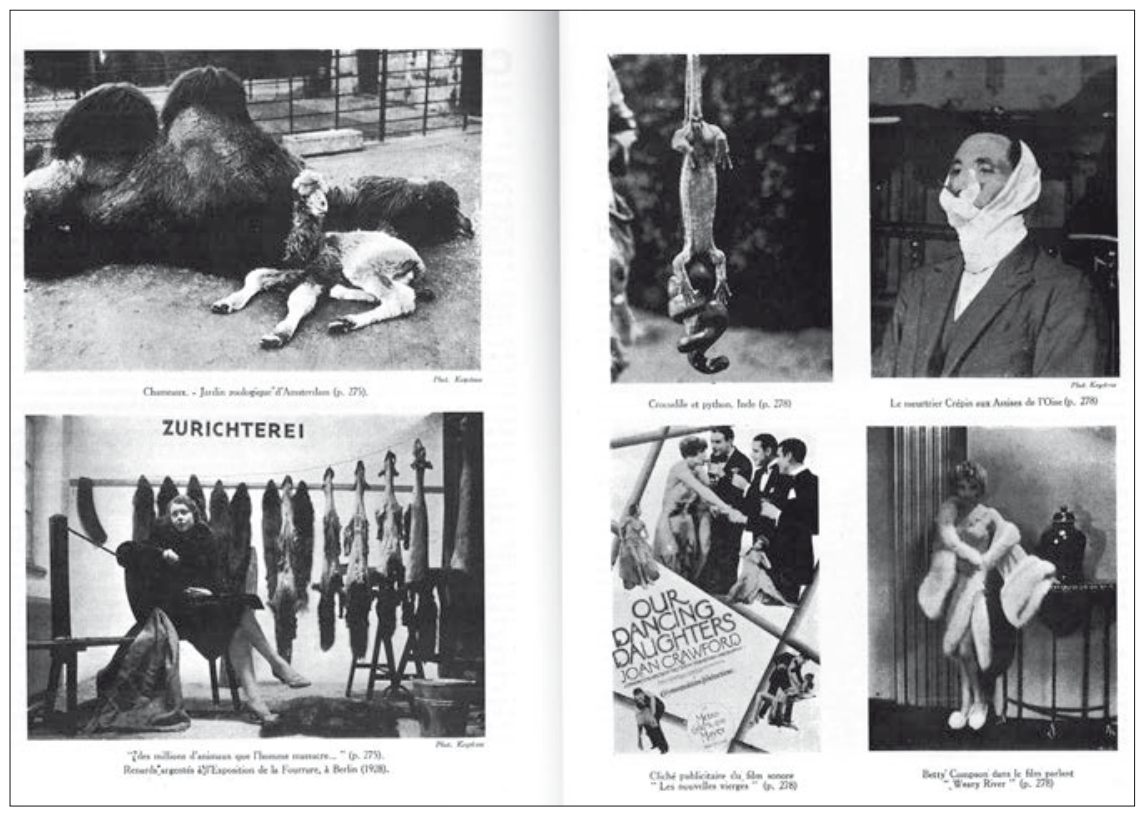

Fig. 4: Camels in the Zoo (Foto Keys tone); promotional pictures for a Fur Trade Fair in Berlin 1928 (Foto Keystone); Crocodile and Python, India; The Murderer Crepin (Foto Keystone); promotional pictures for the Talkies Our Dancing Daughters and Weary River. Picture-pages in Chronique-Dictionnaire, Documents I/5, 1929, p. $276-277$.

the clothesline behind her. Although the crocodile, already half-devoured by a python, seems to be a contrasting image of the cruelty of animals, it is in fact also the result of human action: the frame of the picture is set in such a way that one cannot see the hand that playfully holds the crocodile up to the python. Leiris unites perpetrator and victim in the rubric "Reptiles" and, from a few ethnographic suggestions, constructs a pseudo-symbolic meaning where the reptiles appear as an accurate depiction of human existence, "traversée du haut en bas par la mort et l'amour". ${ }^{17}$ It reads like a parody of the surrealist iconography of the praying mantis, so extremely fascinating because of the simultaneity of mating and death..$^{18}$

The photo Zurichterei corresponds with the caption to the entry "Homme". Therein a source is cited which turns against the slaughter of animals und castigates it as inhumane. The citation and its association emphasize the

17. Documents, year 1, 1929, issue 5, p. 278.

18. Compare Roger Caillois, Le mythe et l'homme, Paris, Gallimard, coll. "Idées," 1972 , p. 35 . 
suppression of everyday cruelty. Eli Lotar's slaughterhouse photos document this in the following issue. They expose the violence of the killing of animals, which is carefully hidden and suppressed from the society's consciousness through physical displacement and local isolation.

Presumably, the dramaturgy of the picture page is drawn from the photograph of the fur-cloaked model standing in front of animal skins to promote a furrier's trade show in Berlin. The montage thwarts the intended purpose and emphasizes its relation to violence, which the photo naively and unsuspectingly nevertheless clearly displays. Within the context of trade and fashion, this is overlooked and remains optically unconscious. Here, it is emphasized and intentionally exposed through the montage, and is consciously made a subject for the following issue under the entry "Abattoir."

An attempt to read the page as a whole reveals that the shifting relationships between the images cannot be made to stand still. There is always something that does not fit, that shifts and does not coalesce. Photography's accessibility makes possible the combination of these photos, which originate from such diverse contexts. There is no other context, no story. They do not organize themselves in accordance with some predetermined discourse; rather they group themselves around points of fascination. In Documents, the photos seem to mould themselves around structures of implicit and explicit violence. The more banal the material, the more interesting the possibilities it offers to create an explosive force that drives against the perception of humans as sentimental. The faits divers from the flood of promotional and stock photos are selected more or less by conscious assumptions. Thereby, it is never a question of mere pictorial objects, but of the anarchistic dynamics that can be generated through their montage with other pictures. This is why the groupings of images, alone and with the texts, are more important than the individual picture or the individual text. Definite positions are avoided in favor of oppositional movements. It was part of the magazine's strategy that classifications and meanings began to shift and interpretations remained unstable.

Here lies the problem haunting every investigation of the pictorial in Documents. Didi-Huberman, who stresses the importance of the pictorial for the journal, claims that one has to consider the pictures as part of a corpus. This would mean that the photos can be categorized in a repertoire guaranteeing an immanent linkage. The manner in which he makes this plausible, however, hides the fact that the illustrative in Documents cannot be portrayed in usual forms of iconographic evidence. It may be satisfying and convincing to group pictorial material together according to similarities, as is the practice of trained 
art historians, and thus to construct contexts, but for the analysis of the pictorial strategies in Documents, it is precisely the disjunctive element which is decisive: the gap, the interval, positioning.

The action and counteraction between the texts and the images opened up new terrains with the tendency to turn against any form of idealism, not only bourgeois but also the anti-bourgeois idealism found in Breton's circle, who reproduced it by fighting it.

\section{TRANSGRESSION}

There is never any reflection on photography in Documents, nor on the function of the pictures. They are simply inserted, as playing cards are tossed onto a table. Bataille is a master of this, and he finds a congenial game partner in André Boiffard. Boiffard took the photos for Breton that are found in the latter's novel Nadja from 1928 and that show the sites of action significant for Breton. They are banal photos without any formal effort. In the meantime, Boiffard turned his back on Breton. Unlike Man Ray, who is present from the very first issue of La révolution surréaliste and from whom he learned his trade, he is not interested in the artificial practices of double exposures and other lab techniques which Surrealist photography employed. He insists on the medium's connection with reality. Using photography as a medium without a single aesthetic pretention is in harmony with the concept of Documents.

The insertion of images is direct and at the same time subtle. They function as a form of abbreviation vis-à-vis written argumentations. The internal disagreements within the journal also use this strategy, as Conor Joyce demonstrated with the dispute between Bataille and Einstein. ${ }^{19}$ In the contest between Einstein and Bataille, Einstein made the first move. In an essay about Picasso's newest paintings in the first issue of Documents, Einstein exposed his concept of the tectonic in relation to the human form. Bataille, whose work evolved in reciprocation and confrontation with the older and already successful Einstein, pursued a systematic inversion of Einstein's construed concept under the heading "Architecture" in the following issue. ${ }^{20}$ In response, Einstein included photos by Karl Blossfeldt in the fourth issue which visually illustrate his thesis of tectonic forms in nature.

19. Joyce, 2003. The reconstruction of the match Bataille/Einstein follows Joyce research.

20. Bataille's critique is that man only constitutes a middle stage between monkeys and monumental architecture. That which Einstein celebrated as tectonic, Bataille dismisses as abhorrent compulsion, which painting rightly seeks to elude. 
This was absolutely in accordance with Blossfeldt's ideas. The illustrated book Urformen der Kunst (Archetypes of Art), which immediately became a bestseller in 1928, was originally to have been titled Architektonische Naturformen (Architectonic Forms of Nature). ${ }^{21}$

Einstein's move was strategically well played. However, Bataille countered the move by positioning his text "Le langage des fleurs" beside it (fig. 5). With good reason, Blossfeldt did not want to include it in his publication because it did not fit in the crystallized harmony he had envisioned. The picture served as Bataille's point of departure for the inversion of all the objectives, which Einstein had in mind with the publication of Blossfeldt's photos. The lyrical title of the text, which seemed to allude to the traditional metaphor "durch die Blumen sagen" (to say something indirectly-literally "to say it through the flowers"), in fact disparaged the conventional language of flowers and paraded their sexual nature. Only through the close-up does the sexual dimension of the plant become obvious. Within the enlargement lies a transgressive element, which in this case demolishes the optical discipline of Blossfeldt's illustrative concept. Bataille reacted to this point in particular and radicalized it through his text.

The fact that he recognized the subversive potential of the enlargement is demonstrated in the mandates that he entrusted to André Boiffard in order to carry on the contest with Einstein. He ordered photos from him of a big toe (fig. 6). The big toe is the misshapen, seldom noticed part of the human body that sets homo sapiens apart from their animal ancestors. The derisive comment in Bataille's "Le gros orteil" is that the big toe is essential to the erect gait of humans, on which humanism bases man's dignity. Today, it would be difficult to get an accurate impression of the impact made by the double page, which

21. Benjamin discussed Blossfeldt's photos for the first time in 1926 under the title "Architektur der Pflanzen" (Architecture of Plants), in Das Illustrierte Blatt, 2.8., 1926. Werner Lindner put Blossfeldt's photos in "Bauten der Technik. Ihre Form und Wirkung. Werkanlagen" (Constructions of Technology), Berlin, Wasmuth Verlag, 1927, beside architectural images to visually evoke similarities between the structure of plants and human construction. It is likely that Einstein came across Blossfeldt's photos in April 1926 in the Gallery Nierendorf. Nierendorf was exhibiting them along with African sculpture, in which Einstein took an interest in "Exoten, Kakteen und Janthur" (Exots, Cacti and Janthur). Einstein probably got prints of the unpublished photographs through the editor Wasmuth. Conor Joyce mentions that Günther and Ewald Wasmuth were friends of Einstein (see Joyce, 2003, p. 65). 


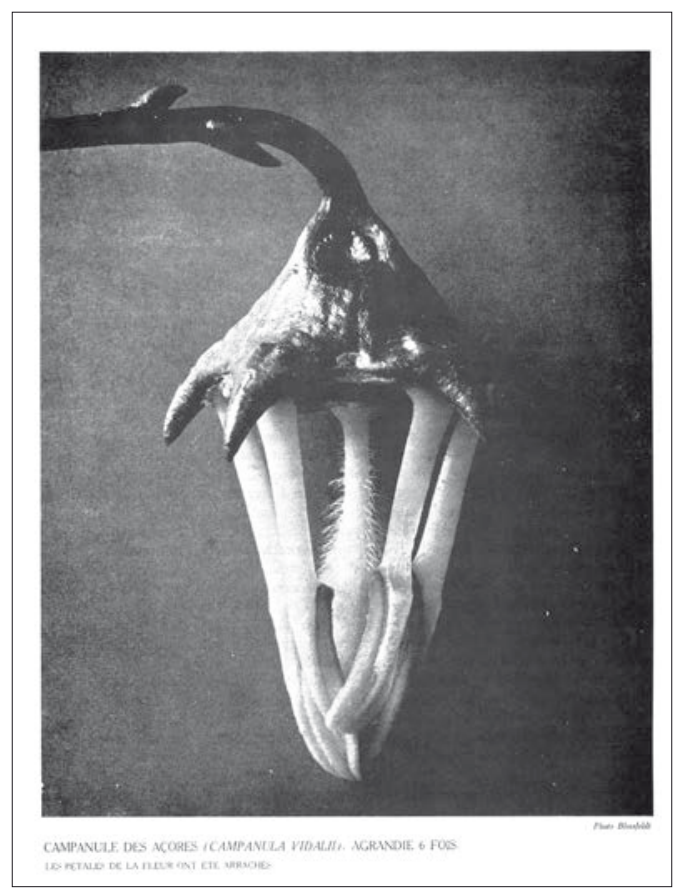

Fig. 5: Karl Blossfledt, Campanula Vidali six-times enlarged. Picture-page accompanying Georges Bataille's article "Le langage des fleurs", Documents I/3, 1929, p.161.

followed Carl Einstein's article on Braque. The toes, enlarged to cover a full page, jump out aggressively from the black background. ${ }^{22}$

The photos ignite the explosive charge that Einstein had unknowingly laid out three issues earlier with Blossfeldt's images. Bataille uses the enlargement as a tool. Scientific images and film close-ups had aroused an awareness of their potential: precision and pathos mark the layout. In the same issue in which the enlarged big toes are depicted, there is a magnified photo of a crab's head. It originated from a popular scientific film by Painlevé. ${ }^{23}$ What must have interested Documents about enlargements is that they undercut the conventional limits of

22. Between the impact then and today stands not only the diminution of the shockwave, but above all the art of the 1980s, in which one can find similar photographic dramatizations of individual body fragments (for instance Geneviève Cadieux, John Copeland, Thomas Florschütz).

23. Jean Painlevé was a biologist. He had contact with the Parisian art scene and worked together with Boiffard and Eli Lotar, among others. Documents, year 1, 1929, issue 6, p. 231. 


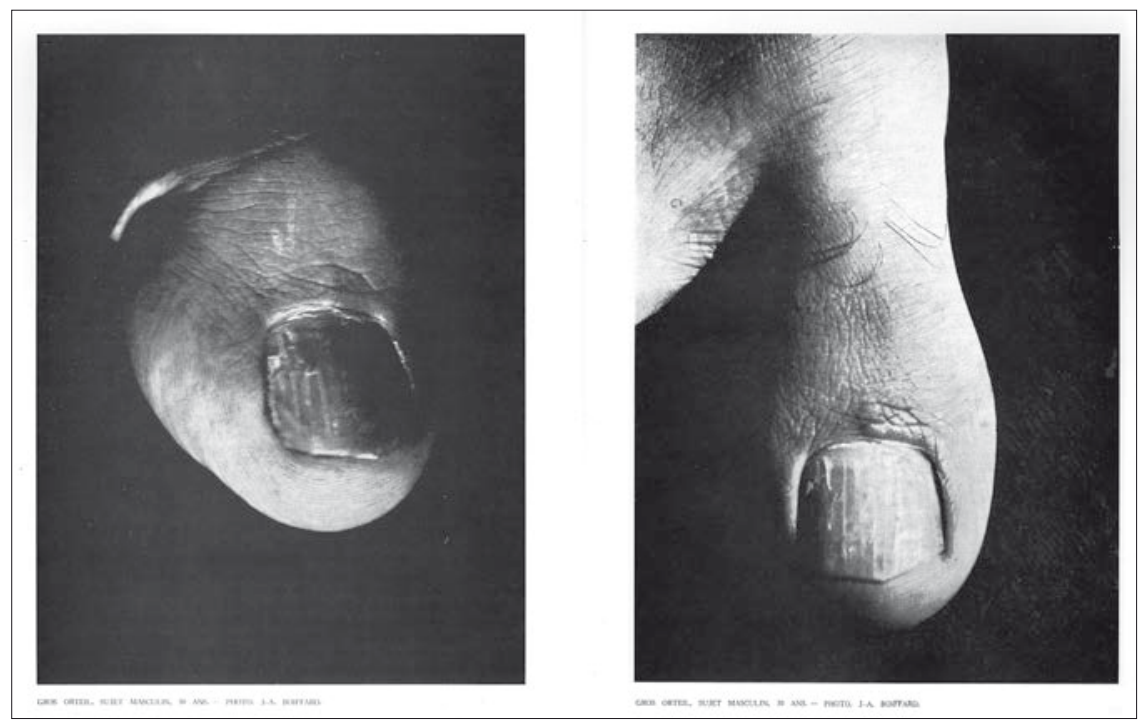

Fig. 6: Jacques-André Boiffard, Big Toe of a Man, 30 years old. Picture-pages accompanying Georges Bataille's article "Gros orteil", Documents I/6, 1929, p. 298-299.

perception without abandoning the realm of the documentary. The enlargement became an instrument of vivisection. This position differentiated itself from the aesthetic functionalistic perspective of the "new vision", as well as from the interest in the fantastic, which the surrealists brought to enlargements. Within the context of Documents, it functions as a "sub-real" practice. It brings forth the materiality of the objects and turns them polemically against both worn-out forms of perception and surrealist presentation itself. In this respect Gros orteil and the crab head surpassed Blossfeldt, whose photos remained within the framework of classic modes of representation. Blossfeldt visually creates a whole out of the details, which in turn represents archetypes. Boiffard's toe appears by contrast monstrous. It is not disfigured, but it is impossible to imagine a whole of which it could be a part. While Blossfeldt's images stand still in perfect symmetry and are simply surrounded by a frame, there is an enormous pressure on Boiffard's images. ${ }^{24}$ The frame cuts and conceals the fact that the other toes are hidden. ${ }^{25}$ Setting the frame in such a way accentuates this break. The toe appears not simply as a fragment, but as though it had been amputated. The camera becomes

24. Compare Rosalind E. Krauss on Man Ray's “Monument to de Sade," 1933. "The Photographic conditions of Surrealism", in Krauss, 1986, p. 87.

25. Picture in Krauss and Livingston (eds.), 1985, p. 65. 
a scalpel. The caption reads like something out of an anatomy book: "Gros orteil, sujet masculin, 30 ans". The caption is as precise as the little hairs on the toe: as deictic as the photo itself. Boiffard's method, which distanced him from all the artistic methods of surrealist photography, exhibits how mere demonstration can function as demontage. Bataille's text with its cultural-historical anecdotes became scandalous only through Boiffard's photographs. They energized his text as Blossfeldt's photographs did with his text on the language of flowers. There is no illustrative rapport. Picture and text maintain a strange autonomy. They rank on the same plain-deictic, provocative. Their juxtaposition generates a correlative friction which heightens awareness. The corroding effects serve the demontage, which does not invite traditional interpretations.

The strategy of subversion through enlargement and partition, which makes it impossible for the observer to perceive the whole, culminates in an entire page of Boiffard's photography exposing the inside of a mouth (fig. 7). ${ }^{26}$ The edge of the photo cuts across the nostrils, exposed through the reclining position of the screaming head. Bataille's text "Bouche" 27 alludes to the de-positioning of the mouth: in an expression of pain the mouth is at the top. (In Picasso's figures of pain of the 1930s, the mouth was also placed at the highest position on the head. ${ }^{28}$ ) The pose of the thrown-back head refers anthropologically as well as iconographically to a state of ecstasy, whereby the limits to the non-human become permeable. Bataille emphasizes the reference to the animalistic in his text. The photo seems out of focus, making the cut of the frame even more poignant. This should not, however, conceal the fact that it is a meticulously staged photograph. The blurriness is the result of deliberate de-articulation.

Boiffard uses light for this in very different ways. He used it in Gros orteil to achieve a dramatization similar to cinema close-ups, and in Bouche the light makes everything appear to be disintegrating. In the extreme close-up of the torn-open mouth, the light fragments in the reflections of the saliva and so dissolves what it first made visible: the inside of the mouth. The camera is sharply focused on the uvula at the back of the throat, which opens and closes the path into the body. The uvula regulates breathing in verbal expression and the entrance to the esophagus. It is important to note that this is not the tongue, as most commentaries suppose. The emphasis is not on the organ with which

26. Documents, year 2, 1930, issue 5, p. 298.

27. Ibid.

28. The culmination of this figure are the despairing women in Picasso's Guernica from 1937 . 


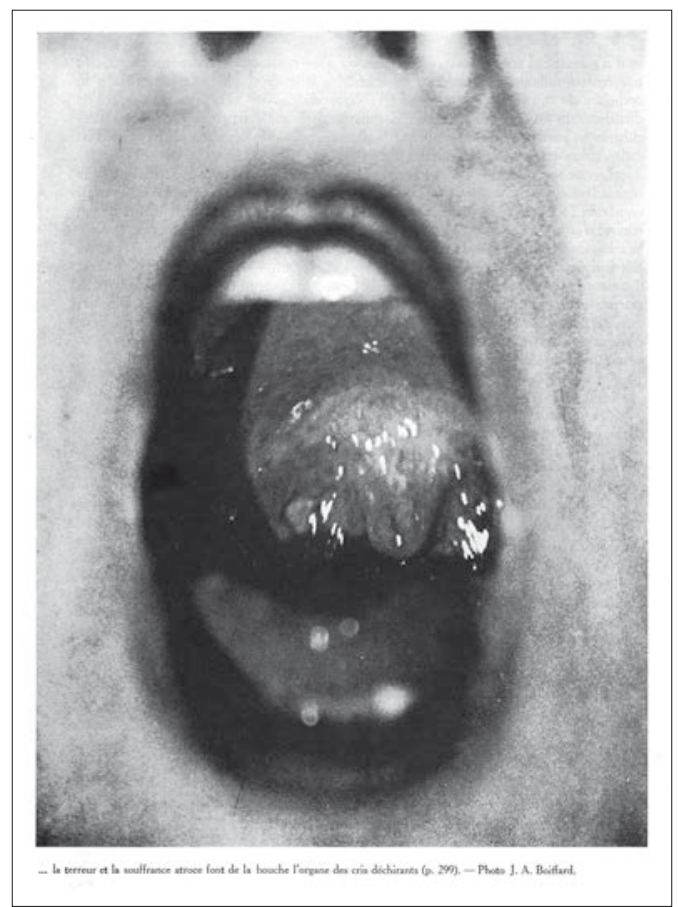

Fig. 7: Jacques-André Boiffard, "Bouche” accompanying Georges Bataille’s article in Chronique-Dictionnaire. Documents II/5 1930, p. 298.

language is articulated, but rather on the inarticulate ability to produce sound. In the Dictionnaire entry "Crachat," which accompanies Bataille's "Informe,"29 Leiris aims at distinguishing between the mouth as the place of language and spittle as the quintessence of shapelessness. ${ }^{30}$ "Bouche" eliminates this division. The illuminated though blurred inside of the mouth opened in outcry alludes to forms of expression prior to and beyond language: the expression of terror, desire, and pain. ${ }^{31}$ Also of note here is the short-circuit between the acoustic and the visual, which evades any semantic classification. The scream not only cancels out language, it also cannot be expressed through language. As presented in the photograph, the cry creates a distortion. Since Lessing's Laokoon essay,

29. Documents, year 1, 1929, issue 7, p. $3^{81-382}$.

30. "Le crachat est enfin, par son inconsistance, ses contours indéfinis, l’imprécision relative de sa couleur, son humidité, le symbole même de l'informe, de l'invérifiable, du non-hiérarchisé..."Documents, year 1, 1929, issue 7, p. 382.

31. The text reads: “... la terreur et la souffrance atroce font de la bouche l'organe des cris déchirants.” Documents, year 2, 1930, issue 5, p. 299. 
the scream has consistently been a subject of aesthetic debate. To portray the scream meant to render in space what can only be rendered in time. Johanne Lamoureux wrote about the media paradox: "La représentation du cri constitue un scandale plastique: elle introduit dans l'image une plage de dé-formation." 32 In Boiffard's photo, the deformation was presented by way of the depiction of the mouth. The dissolution of limits, which serves as a de-definition, clearly relates to Bataille's concept of the "informe." The inarticulateness of the scream appears immediate. Thus, the photo undercuts those categorizations and media allocations that separate spatial from temporal art and aim at controlling the allocation of assignment for every medium. ${ }^{33}$

As with many texts in Documents, the photograph is the medium and tool of transgression. It is about more than the juxtaposition of photo and text. The photos do not illustrate the text, nor do the texts explain the photos. As neither is subordinate to the other, the result is a tense parenthesis. The visual develops a critical function which encroaches on the form of the text. The photos become increasingly deictic.

\section{DÉFAIRE}

It is the visual strategies employed in Documents that make the experimental exercises in perception unique. The photos are like purposeful blows, wicked jokes and impudent answers.

In his second Surrealist Manifesto, Breton had worked extensively on Bataille's interpretation of "mouche sur le nez d'orateur" in the text "Figure humaine." ${ }^{34}$ He sought to demolish Bataille’s renegade "bas matérialisme." He skillfully uncovered a figure of old rhetoric in the text, which enabled him to proceed: "Nous ne parlons si longuement des mouches que parce que M. Bataille aime les mouches. Nous, non..." 35

32. Johanne Lamoureux, "Cris et médiations entre les arts. De Lessing à Bacon," Protée, vol. 28, n³ "Mélancolie entre les arts", Winter 2000-2001, p. 13-21.

33. The attempt at medium-specific allocation was pursued through to Clement Greenberg's concept of modernism. "Towards a Newer Laocoon," Partisan Review 7, JulyAugust 1940, p. 296-310, is the name of one of his key texts.

34. Documents 1929, year 1, issue 4, p. 194-201.

35. André Breton in La révolution surréaliste, issue 12, December 1929, p. 15. 
In the last edition of Documents, Bataille responded to Breton's berating observation with Papier collant et mouches. ${ }^{36}$ Boiffard's photo, which captured a close-up of an adhesive flytrap, covers a whole page. Photos were commissioned at the Institut de Microphotographie, which disintegrated the figure of the fly to the untrained eye through a 27 -fold enlargement of the image. ${ }^{37}$ Here too one finds the discontinuity through disruption, which makes it impossible to visualize a whole apart from the details. Ironically these pictures of flies visually explore Breton's rhetorical figure, which he used against Bataille, and exposes the argument to ridicule.

Breton finally understood the game. On a double-page in the first issue of Surréalisme au service de la révolution, the follow-up of La révolution surréaliste with a new layout and with a greater proportion of pictures, he exhibited images from Luis Buñuel's film L'âge d'or (1930). One is focused on the mouth and the other on the big toe. It is the big toe of a statue on which a woman lustfully and ecstatically sucks in a manner of displaced action. ${ }^{38}$ Breton responded to the radical form of "Le gros orteil" with a psychoanalytical figure of a shift from toe to phallus. This conforms to a metaphorical practice in surrealism that Documents put under attack. Documents is deictic and apodictic in tone and image. There is no room for metaphor. It refers to scientific discourse only to explode it. At the end of the demontage work of Documents, the path into practice has been opened up.

The ethnologists went into fieldwork (Marcel Griaule, Michel Leiris, and André Schaeffner left for an expedition to Dakar-Djibuti); the photographer André Boiffard became a radiologist; Robert Desnos ceased to write film critiques and began instead to shoot documentary films; Georges Bataille opened an "academy"; and, finally, the art theorist Carl Einstein joined the Spanish anarchists.

36. Picture in Georges Bataille, "L'esprit moderne et le jeu des transpositions" Documents, year 2, issue 8, 1930, p. 48. Original title: Papier collant et mouches, by J. A. Boiffard.

37. Ibid., p. 51.

38. The caption reads: "Il y a longtemps que je l'attendais ce moment. Ah! Quelle joie d'avoir assassiné nos enfants!" Dawn Ades also hinted at the relationship between the images. Compare Ades, 1985, p. 175. 
And yet "défaire," the practice of de-defining, is virulent in its differing manifestations, and perhaps most successful in the type of art that seeks to free itself from "art": art practices that are more interested in the processes than in the results. ${ }^{39}$

Translated from the German by Olivia Landry and revised by Richard Gardner

39. The interest in the de-centered ethnographic gaze is found in the arts as well as mediated through Jean Rouch's cinema. Since the 1950s experimental films activated the interspace between pictures and text. Chris Marker's films work with the dynamic derived from the techniques Documents experimented with. The activation of the interspace between picture and text became popular in the realm of visual art from the 1970s onwards with photo-based works. 